\title{
A QUESTÃO HÍDRICA E A DINÂMICA DE CONSUMO DE ÁGUA PARA ABASTECIMENTO DOMÉSTICO NA CIDADE DE ITUIUTABA - MG
}

\author{
Maria Cristina Moreira Penna \\ Universidade Federal de Uberlândia \\ Programa de Pós Graduação em Geografia do Pontal, Ituiutaba, MG, Brasil \\ crispenna@ufu.br \\ Rildo Aparecido Costa \\ Universidade Federal de Uberlândia \\ Programa de Pós Graduação em Geografia do Pontal, Ituiutaba, MG, Brasil \\ rildocosta@ufu.br
}

\begin{abstract}
RESUMO
A importância da conservação da água como recurso natural em face aos problemas hídricos enfrentados nas cidades atualmente e a necessidade de se manter a qualidade e disponibilidade hídrica para o consumo humano, motivaram essa pesquisa. $O$ objetivo dessa pesquisa foi compreender a disponibilidade hídrica e a dinâmica de consumo da água para o abastecimento doméstico. Para se compreender a disponibilidade hídrica do município utilizou-se a metodologia do Balanço Hídrico proposto por Thornthwaite e Mather (1955), além dos dados climáticos fornecidas pela Estação Automática de Ituiutaba - MG (1998 a 2018), pertencente ao Instituto Nacional de Meteorologia (INMET). Foi utilizado também, a metodologia de anos-padrão (Tavares 1976). A análise final dos dados avalia a qualidade e disponibilidade hídrica como satisfatórias para atender o abastecimento doméstico. Porém, o consumo de água elevado em períodos críticos de recarga de água nas bacias hidrográficas alerta para a necessidade do uso racional de modo que a demanda não torne a disponibilidade insuficiente futuramente. Quanto à qualidade hídrica, a SAE tem mostrado eficiência nos serviços prestados e, para manter esses resultados, depende também da colaboração da população e de políticas públicas em relação ao seu uso e ocupação.
\end{abstract}

Palavras-chave: Balanço hídrico. Disponibilidade hídrica. Abastecimento doméstico.

\section{WATER AVAILABILITY AND THE DYNAMICS OF WATER CONSUMPTION FOR DOMESTIC SUPPLY IN THE CITY OF ITUIUTABA - MG}

\begin{abstract}
The importance of water conservation as a natural resource in view of the water problems faced in cities today and the need to maintain water quality and availability for human consumption, motivated this research. The objective of this research was to understand the availability of water and the dynamics of water consumption for domestic supply. To understand the municipality's water availability, the Water Balance methodology proposed by Thornthwaite and Mather (1955) was used, in addition to the climatic data provided by the Ituiutaba Automatic Station - MG (1998 to 2018), belonging to the National Meteorological Institute (INMET). The standard years methodology was also used (Tavares 1976). The final analysis of the data assesses water quality and availability as satisfactory to meet domestic supply. However, high water consumption in critical periods of water recharge in river basins warns of the need for rational use so that demand does not make availability insufficient in the future. As for water quality, SAE has shown efficiency in the services provided and, to maintain these results, it also depends on the collaboration of the population and public policies in relation to its use and occupation.
\end{abstract}

Keywords: Water balance. Water availability. Domestic supply.

\section{INTRODUÇÃO}

A água, essencial para nossa sobrevivência e para diversas atividades do nosso cotidiano, é um recurso natural que pode ter sua disponibilidade ameaçada seja por ações antrópicas, consumo excessivo ou, pelas condições climáticas de determinados locais. Sua distribuição no planeta se divide em águas doces 
e salgadas, sendo que a água doce, que é apropriada para o consumo humano, embora não utilizada, encontra-se em uma pequena parcela de $3 \%$. Dessa parcela, $75 \%$ estão congeladas nas calotas polares e 10\% são reservas em aquíferos (TUNDISI e TUNDISI, 2011). Ou seja, a quantidade disponível para suprimento a nível global é bastante reduzida e não é homogênea em todos os lugares.

No Brasil, segundo informações divulgadas pela Agência Nacional das Águas (ANA), a demanda de água é crescente e a evolução do seu uso tem relação direta com o desenvolvimento econômico (tais como agricultura e pecuária) e com o processo de urbanização no país. No entanto, paralelamente ao aumento na demanda, observou-se uma evolução da gestão das águas, principalmente pela criação de legislação específica de proteção dos recursos hídricos. Isso ocorreu devido principalmente ao aumento da demanda por diversos setores.

A maior parte da água doce disponível é consumida para irrigação em atividades agrícolas. Entre as atividades humanas que consomem água, os três grandes setores que se destacam são: a agricultura que corresponde por cerca de $70 \%$ da água consumida globalmente, a indústria, que consome $22 \%$ e, o consumo doméstico, responsável por $8 \%$ (CALHEIROS e SILVA, 2014). São muitos os benefícios que o uso da água oferece ao homem, razão pela qual, a maioria das cidades e vilas se desenvolveram nas proximidades de cursos d'água visando, principalmente o abastecimento doméstico.

Por sua utilidade e seus múltiplos usos, a água é essencial como fonte de recursos, tanto para o uso social quanto econômico, porém seu uso e manejo inadequados, tais como lançamento de esgoto in natura, contaminação por agroquímicos dentre outros, pode resultar em uma redução significativa no grau de potabilidade, podendo afetar sobremaneira o abastecimento doméstico.

Atualmente, na cidade de Ituiutaba/MG, o abastecimento de água é realizado pela Superintendência de Água e Esgoto (SAE) retirando água do Ribeirão São Lourenço para essa finalidade. A intenção em um futuro próximo, é que o abastecimento ocorra captando água somente do médio curso do Rio Tijuco, de onde já se faz eventuais retiradas em períodos de baixa vazão do Ribeirão São Lourenço desde 2002, quando foi inaugurada uma nova estação de captação.

Em Ituiutaba já houve períodos críticos, como nos anos de 2002 e 2015, em que a vazão dos rios chegaram a níveis alarmantes exigindo medidas de urgência, como por exemplo, o rodízio de abastecimento de água em alguns bairros da cidade. Isso traz um alerta em relação à média de consumo da população. Contudo, há a necessidade de conhecer melhor, através de estudos, a disponibilidade hídrica, bem como seu uso pela população.

Diante disso, destacou-se a importância de realizar uma avaliação da disponibilidade hídrica para o abastecimento doméstico em Ituiutaba, sendo este, o objetivo geral aqui proposto. Para alcançar o objetivo foram utilizados métodos adequados como o balanço hídrico do município, definição de "anos padrões", além da análise dos dados de consumo da cidade.

É importante ressaltar que o uso inapropriado da água pode ameaçar sua disponibilidade e ser um fator limitante para o desenvolvimento econômico das cidades. Isso nos leva a pensar em ações que devem ser implementadas em busca de uma solução. Por esse e outros motivos acima elencados, justificou-se a realização desta pesquisa no município de Ituiutaba - MG.

\section{LOCALIZAÇÃO E APORTES DO MEIO FÍSICO DA ÁREA DE ESTUDO}

A área de estudo foi definida a partir de um recorte espacial onde estão localizadas as duas estações de captação de água da Superintendência de Água e Esgoto (SAE), sendo a principal no Ribeirão São Lourenço e, a secundária, no médio curso do Rio Tijuco no Lago da Usina Salto de Moraes, numa extensão de aproximadamente 5 quilômetros da margem do Rio Tijuco até a Estação de Captação do São Lourenço (SAE, 2018).

O recorte abrange uma pequena parcela dos municípios limítrofes de Canápolis, Monte Alegre de Minas (em um trecho do médio curso do Rio Tijuco), parte do município de Prata (onde se encontram as nascentes do Ribeirão São Lourenço) e, tem sua maior parte no município de Ituiutaba, que é o município de interesse deste estudo, para avaliação da qualidade e disponibilidade hídrica para abastecimento doméstico (Mapa 1).

$\begin{array}{llllll}\text { Caminhos de Geografia } & \text { Uberlândia-MG } & \text { v. } 21, \text { n. } 77 & \text { Out/2020 } & \text { p. 234-252 } & \text { Página } 235\end{array}$


O município se localiza na porção Oeste da Mesorregião do Triângulo Mineiro/Alto Paranaíba, onde o mesmo é sede da Microrregião de Ituiutaba. Possui uma área de $2.598,046 \mathrm{Km}^{2} \mathrm{com}$ uma população de 97,171 habitantes em 2010, estimada em 104,067 em 2018 e, densidade demográfica de 37,40 hab/Km² (IBGE, 2010).

Mapa 1 - Localização da área de estudo.

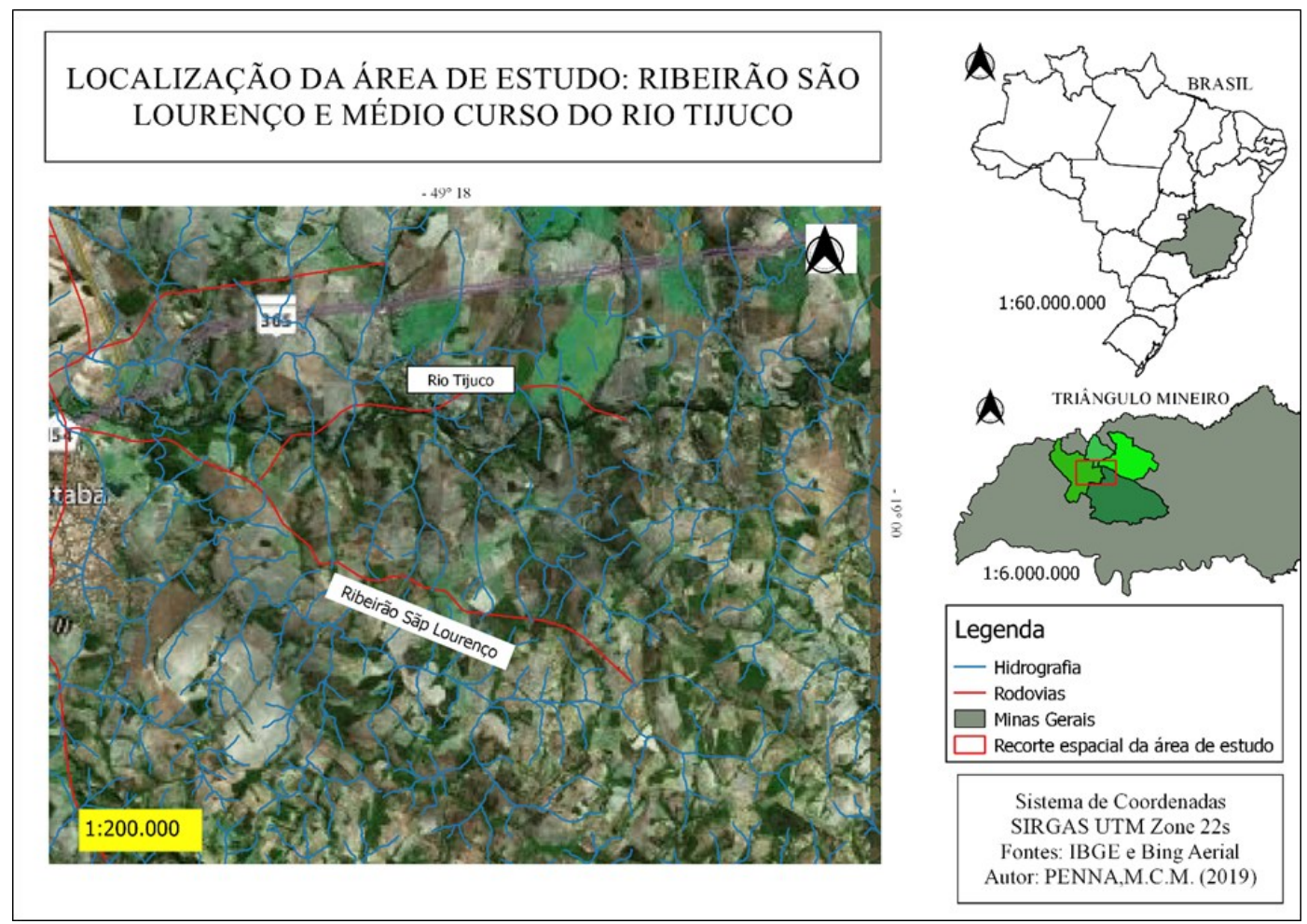

Na divisão hidrográfica nacional, instituída pelo Conselho Nacional de Recursos Hídricos, que estabelece as doze regiões hidrográficas brasileiras, o município de Ituiutaba está localizado na bacia do Paraná. Essa região hidrográfica abrange $10 \%$ do território nacional ocupando uma área de $879.860 \mathrm{Km}^{2}$, sendo a região mais populosa e com maior desenvolvimento econômico do país, por isso possui uma demanda maior pelos recursos hídricos.

Mais precisamente, na região hidrográfica do Paraná, o município de Ituiutaba, está inserido na bacia hidrográfica do Rio Paranaíba. Torna-se importante localizar a área de estudo ao destacar que, estando inserida em uma bacia hidrográfica, todos os processos que envolvem recarga e descarga de água das bacias hidrográficas devem ser considerados. Como apontado por Calheiros e Silva (2014) é na bacia hidrográfica que ocorre o balanço de água no solo, separando a quantidade de água que irá se infiltrar e escoar superficialmente.

Em relação aos sistemas atmosféricos, a área estudada está a influência dos sistemas intertropicais e polares. Nos meses de verão, o município sofre uma maior influência dos sistemas equatoriais (Massa Equatorial Continental) e nos meses de inverno atua com mais intensidade o sistema polar (Massa Polar Atlântica). Nota-se também a atuação da mTac (FOLI e COSTA, 2016).

É comum, no período chuvoso, a ocorrência das chamadas ZCAS (Zona de Convergência do Atlântico Sul), que se estende da porção sul da região amazônica ao litoral da região sudeste, passando sobre a região estudada, provocando nebulosidade, causando chuvas por dias. As estações de primavera e outono são consideradas de transição seca/chuvosa e chuvosa/seca, respectivamente. (MENDES e QUEIROZ, 2011). 
As nascentes do Ribeirão São Lourenço se localizam no município de Prata a uma altitude em torno de 750 metros e, o curso principal drena no sentido SE - NW, com desembocadura no médio curso do Rio Tijuco a uma altitude de 500 metros. O Rio Tijuco (que nasce no município de Uberaba) drena no sentido E - W, atravessando os municípios de Monte Alegre de Minas, Canápolis e Ituiutaba a altitudes entre 460 e 500 metros, dentro do recorte espacial delimitado para área de estudo.

As altitudes da área de estudo estão representadas no Mapa 2, variando entre 461 metros nas partes mais baixas do terreno (fundos de vale e áreas de várzea) e 775 metros nas partes mais altas (áreas de topo, divisores de água). Pela variação e distanciamento entre as cotas altimétricas se percebe a declividade do relevo, muito relevante para escolha das atividades a serem desenvolvidas e para avaliação do risco de processos erosivos fluviais e pluviais.

Mapa 2 - Hipsometria do Ribeirão São Lourenço e médio curso do Rio Tijuco.

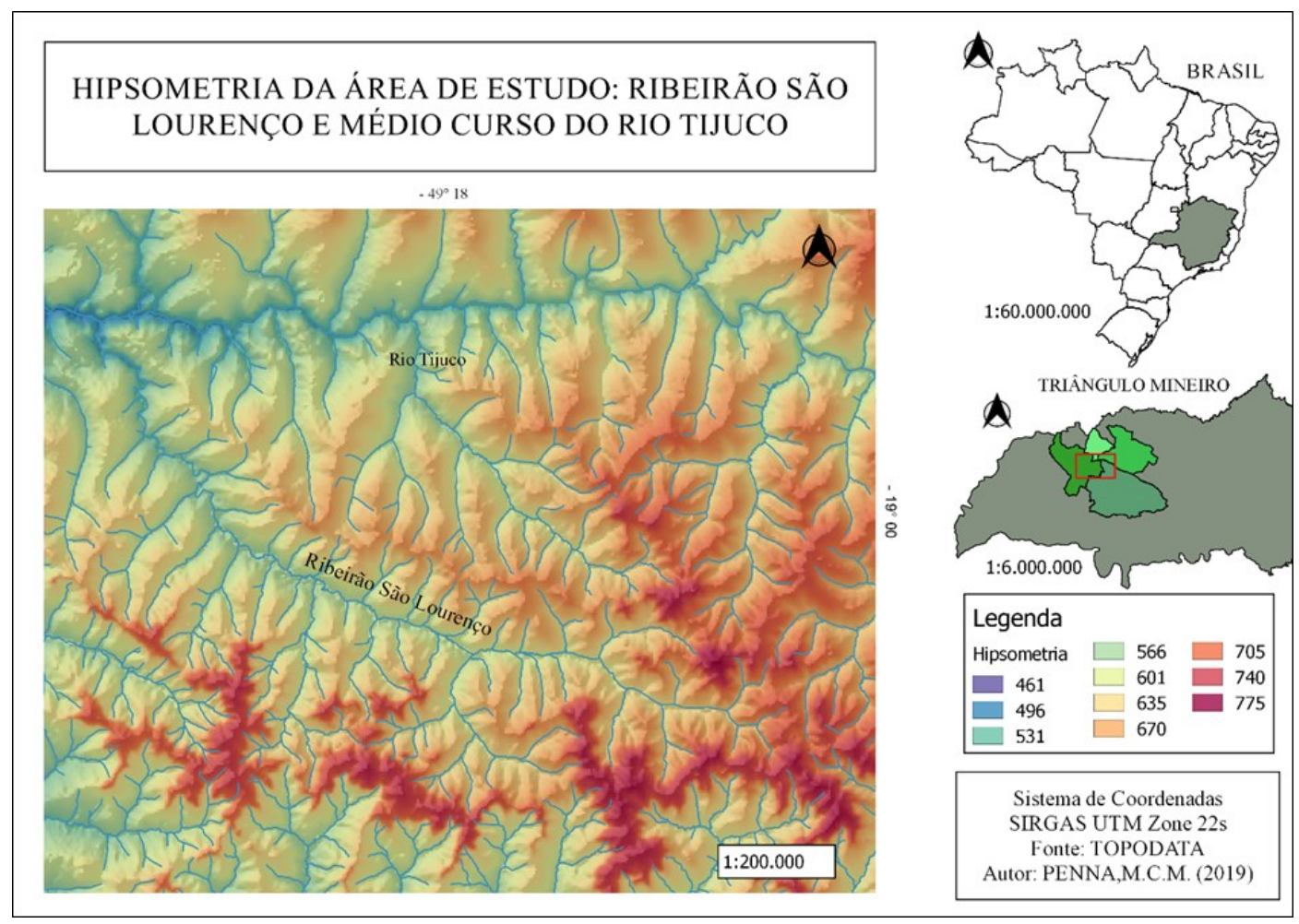

As bacias hidrográficas apresentam um padrão de drenagem que consiste nas formas desenvolvidas pelos cursos d'água com base no comportamento da drenagem em relação ao substrato rochoso e a morfologia dos canais (GROTZINGER e JORDAN, 2013). Na área de estudo os cursos d'água se identificam com um padrão de drenagem dendritíco, com base na classificação proposta por Christofoletti (1980). Esse padrão se caracteriza pela ramificação semelhante aos galhos de uma árvore, é típico de terrenos onde o substrato rochoso é uniforme, como os de rochas sedimentares com acabamento horizontal, característico da região.

A litologia da área em que o recorte espacial deste estudo se insere é descrita por Baccaro e Santos (2014) como representada pelas rochas sedimentares, sobretudo do Grupo Bauru, Formações Marília, Adamantina e Uberaba, e Grupo São Bento, Formação Serra Geral e Arenito Botucatu. Em alguns trechos do médio curso do ribeirão São Lourenço é possível encontrar afloramentos de basalto, rocha ígnea da Formação Serra Geral (Figura 01).

Para Baccaro e Santos (2014), a paisagem se configura sob influência das características climáticas da região, assim ocorre a dissecação do relevo incidindo na drenagem e os processos erosivos fazem o retrabalhamento das vertentes. Para os autores, as alternâncias entre clima úmido e seco favoreceram o rebaixamento do relevo sendo algumas áreas mais resistentes ao processo erosivo. Tais feições, que se conservaram, são os chamados relevos residuais. 
Figura 01 - Afloramento de basalto da formação Serra Geral na margem do Ribeirão São Lourenço.

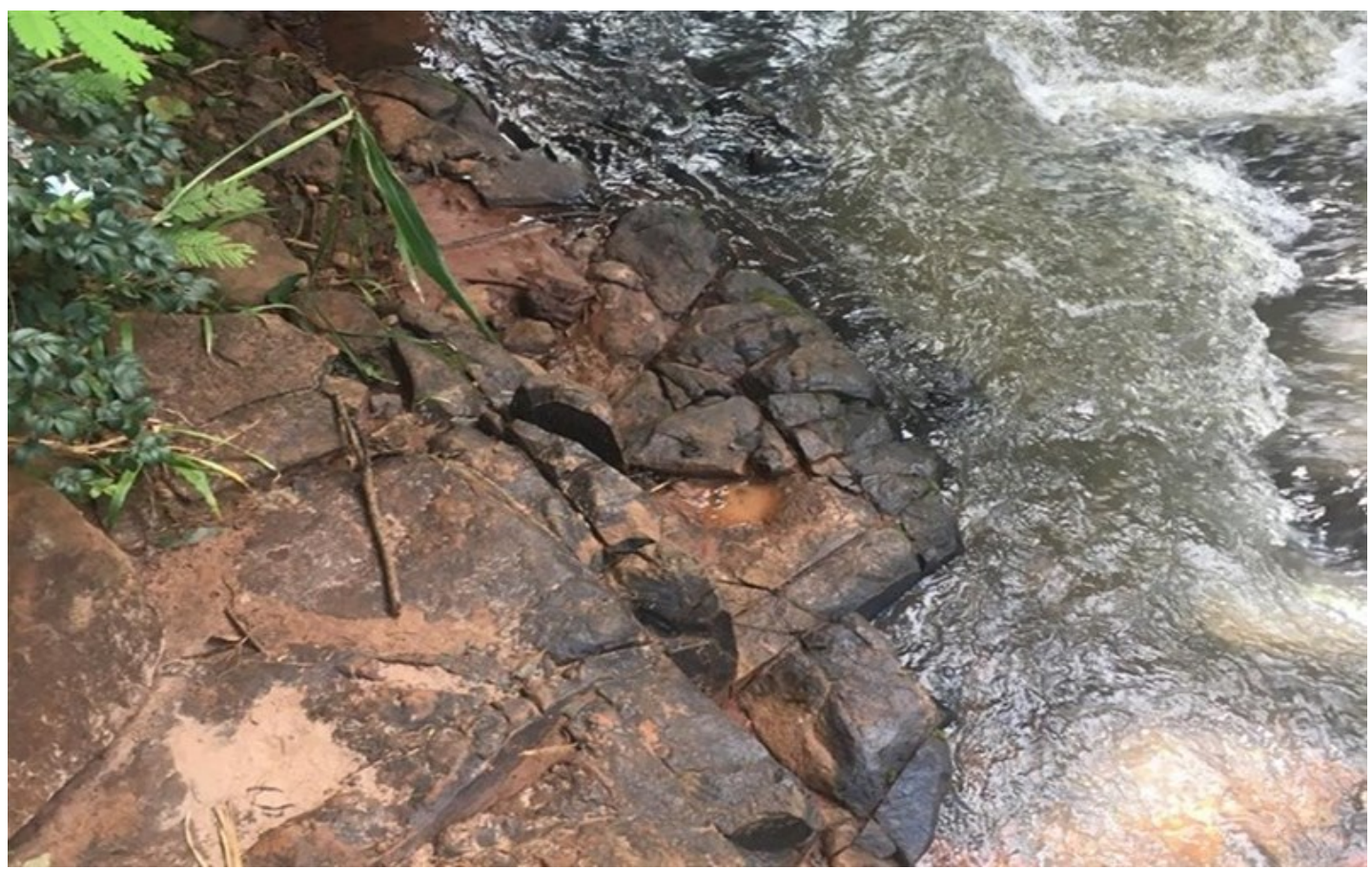

Em relação a declividade do terreno, na área de estudo foram encontradas cinco classes de declividade que variam de 0 a 22,4\%, representadas por cores, conforme ilustra a legenda do Mapa 3 . A cor vermelha, que representa declividade entre $17,1 \%$ e $22,4 \%$ pode ser observada em algumas poucas áreas de topo ao Sudeste e, a Sudoeste, em maior concentração. Também se observa em vários trechos do médio curso do Rio Tijuco e no baixo curso do Ribeirão São Lourenço, próximo a foz.

Mapa 3 - Declividade do Ribeirão São Lourenço e médio curso do Rio Tijuco.

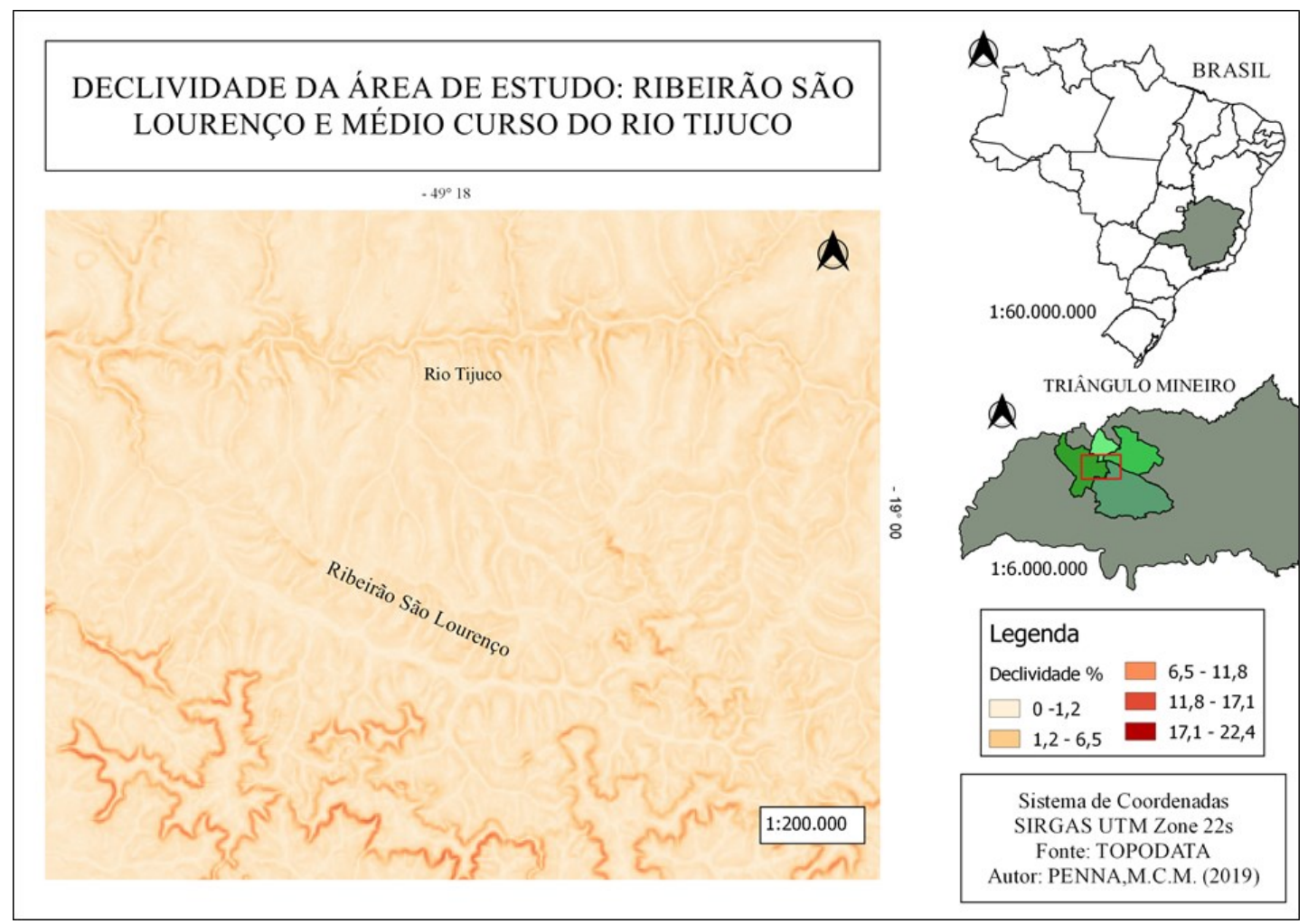


Nos mesmos locais também ocorre declividade entre $11,8 \%$ e $17,1 \%$ representada pela cor vermelho claro, de modo que, as maiores declividades se apresentam em quantidade menor na área de estudo. No domínio das vertentes, a declividade está entre 6,5\% e 11,8\%, representada pela cor laranja, em proximidade com um tom mais claro da cor laranja, onde a declividade está entre $1,2 \%$ e $6,5 \%$, reduzindo gradativamente.

A pedogênese é favorável nestes locais pelo fato de haver maior infiltração de água que resulta em intemperismo químico no material rochoso. Na cor amarelo claro, mais evidente e em maior predominância no mapa, a declividade está entre 0 e 1,2\%, nos fundos de vale, entre os cursos d'água.

Quanto maior for a infiltração de água no solo, maior será recarga de água para os aquíferos. Isso depende não apenas da permeabilidade dos materiais de subsuperfície, mas também da baixa declividade do terreno, pois, apenas uma parte do volume de água das chuvas consegue atingir a superfície dos terrenos e dar início a infiltração (ALVARENGA; BARISON; DIAS PONS, 2014).

Os três tipos de solo encontrados na área de estudo estão representados no Mapa 3, são Argissolo, Cambissolo e Latossolo. Sendo este último, encontrado em predominância em comparação ao Cambissolo e Argissolo.

Latossolos se situam normalmente em relevo plano a suave-ondulado, com declividade que raramente ultrapassa $7 \%$, o que facilita a mecanização. No Cerrado, ocupam praticamente todas as áreas planas a suave-onduladas, sejam chapadas ou vales. Ocupam ainda as posições de topo até o terço médio das encostas suave-onduladas, típicas das áreas de derrames basálticos e de influência dos arenitos (EMBRAPA, 2019).

Mapa 6 - Tipos de solos da área de estudo.

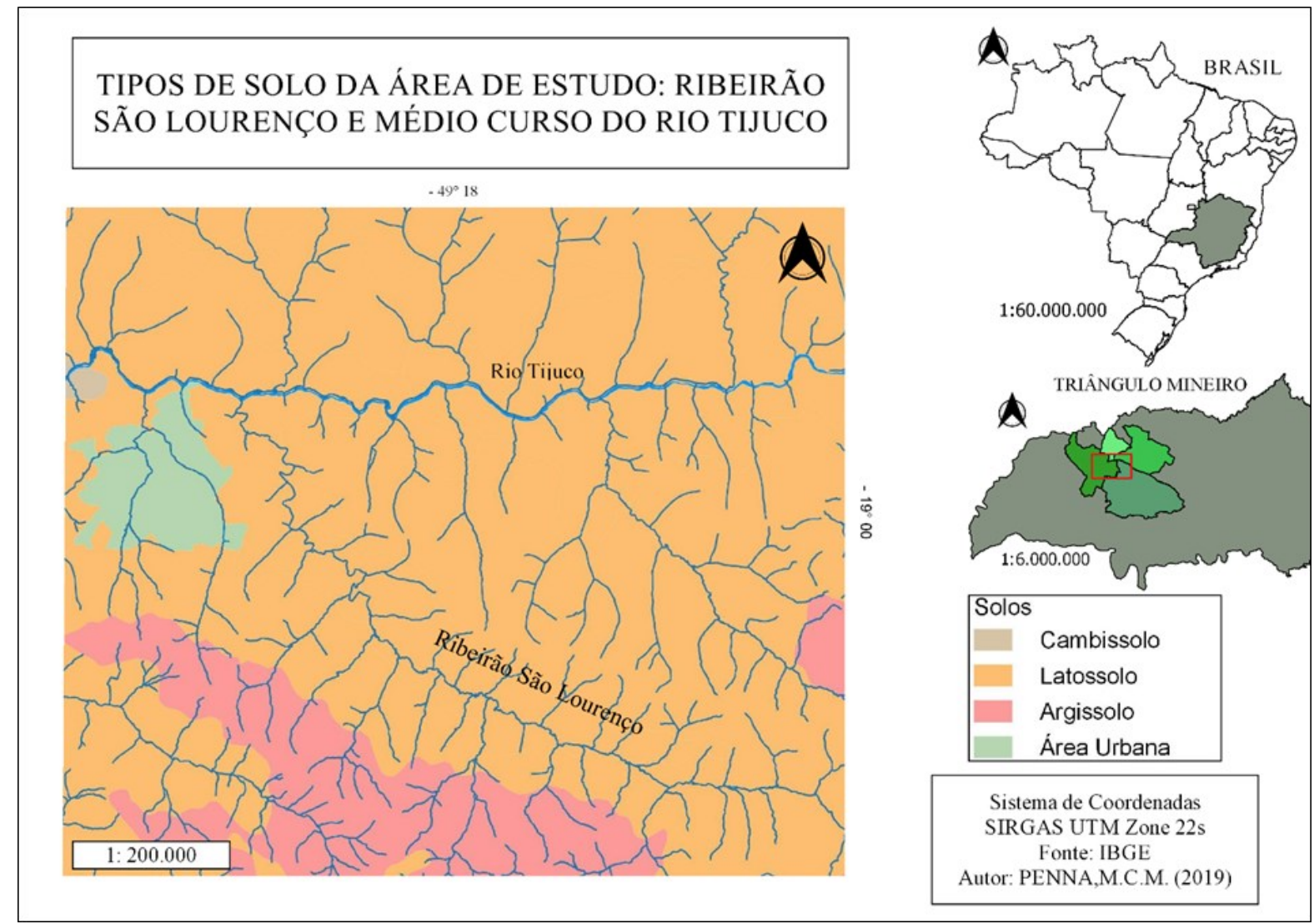

Apresentam teor de silte inferior a $20 \%$ e argila variando entre $15 \%$ e $80 \%$. São solos com alta permeabilidade à água, podendo ser trabalhados em grande amplitude de umidade. Além de profundos,

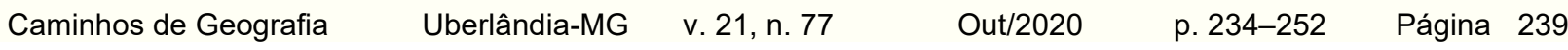


são porosos, bem drenados, bem permeáveis mesmo quando muito argilosos, friáveis e de fácil preparo. Favorecem o armazenamento de água e a preservação deste recurso natural.

\section{METODOLOGIA}

A avaliação da disponibilidade hídrica teve início com a elaboração do balanço hídrico. Para isso, foram coletados dados de vazão e precipitação (disponibilizados pela ANA - Agência Nacional das Águas) e temperatura (Extraída dos dados do INMET - Instituto Nacional de Meteorologia)

Foi utilizado para o balanço hídrico o método proposto por Thornthwaite e Mather (1955). De acordo com Amorim Neto (1989), "O balanço hídrico é definido como uma contabilidade de entrada e saída de água do solo. A entrada de água é representada pela precipitação ou irrigação e a saída pela evapotranspiração potencial".

Os dados obtidos foram tabulados no Software Excel 2013 e passaram por tratamento estatístico, a disposição em planilha foi possível através da adaptação à condições de clima tropical, desenvolvida por Rolim e Sentelhas (1999). A partir de tabelas e gráficos foi elaborado o balanço hídrico e posterior avaliação de excedente e deficiência hídrica na área de estudo. Em uma série histórica de vinte e um anos o período avaliado foi de 1998 a 2018. A falta de dados completos nos anos anteriores a 1998 não permitiu o uso da série padrão de trinta anos, recomendada para avaliar a dinâmica do clima.

As informações disponibilizadas pela ANA foram obtidas pelos registros da estação meteorológica de código 01849020 operada pelo Instituto Nacional de Meteorologia (INMET), localizada no município de Ituiutaba entre as coordenadas Latitude $-18,58$ e Longitude - 49,21 a uma altitude de 560 metros. É uma estação do tipo PPrECT de acordo com a identificação descrita no inventário de estações da ANA em que: $\mathrm{P}$ - indica estação com pluviômetro; R - indica estação com registrador (pluviógrafo); $\mathrm{E}$ - indica estação com tanque evaporimétrico "A"; C - indica estação climatológica e T - indica estação telemétrica.

Como subsídio para avaliar a disponibilidade hídrica, utilizou-se o estudo denominado "anos padrões" em que se definem anos "normal", "seco" e "chuvoso. Os anos padrões podem ser definidos a partir da análise rítmica (que estuda a dinâmica do clima), apresentada por Monteiro (1971). Os critérios para defini-los são apresentados por Tavares (1976).

Como o balanço hídrico trabalha com dados diários de longos períodos, isso permitiu a definição de anos padrões através da análise rítmica, pois, conforme explica Monteiro (1969, p. 13): [...] é pela sucessão que se percebem as diferentes combinações dos elementos climáticos do quadro geográfico. É a sequência que conduz ao ritmo, e o ritmo é a essência da análise dinâmica.

A utilização do estudo de anos padrões obtidos com a análise rítmica do período de 1998 a 2018, aplicando o cálculo do coeficiente de similaridade multidimensional (através da fórmula $D=\sqrt{ }\left(\sum d^{\wedge}(2)\right)$ ), resultou na definição de três "anos padrões": 2004 como ano padrão normal, 2007 como ano padrão seco e, 2008 como ano padrão chuvoso. O cálculo se aplicou a dados de chuva, por ser um evento climático que pode ter uma distribuição muito irregular com desvios representados por situações extremas como nos anos de 2007 e 2008.

Nesta perspectiva, um ano "normal" se define como aquele em que a distribuição da precipitação anual de determinado local é semelhante à distribuição das precipitações médias de vários anos para o mesmo local. Os anos "seco" e "chuvoso" se definem por apresentarem distribuição anual de precipitação que se desviam muito de dados médios obtidos anteriormente, tanto em falta quanto em excesso de precipitação (TAVARES, 1976).

Após a definição de "anos padrões" dentro do período estudado investigou-se, para fins de comparação, o consumo médio de água da população através de dados fornecidos pela própria SAE (Superintendência de Água e Esgoto) e de reportagens do município relacionadas ao tema, principalmente em períodos críticos de redução no abastecimento. Definir anos padrões possibilitou analisar a dinâmica do consumo de água em Ituiutaba - MG em um ano seco, em um ano chuvoso e, em um ano normal, de forma 
sazonal, identificando os períodos do ano em que mais se consome água com o abastecimento doméstico.

Os dados disponibilizados pela SAE se referem ao volume de água tratada, em $\mathrm{m}^{3}$, produzida para abastecimento da cidade entre 1998 e 2018, e são complementares aos dados da ANA que trazem informações pluviométricas e fluviométricas do município em uma série histórica de trinta e um anos, no período de 1987 a 2018.

Para conhecer o valor exato da medida de $\mathrm{m}^{3} \mathrm{em}$ litros foi necessário multiplica-lo por 1.000. Em seguida, dividiu-se o valor resultante pelo número de dias do ano (365) para chegar a um valor diário de consumo da população, de forma geral. Para saber o quanto uma pessoa consome por dia, o resultado do valor diário foi dividido pelo número da população estimada no ano de interesse. Assim, com o resultado do balanço hídrico que revela o potencial hídrico natural do município, com o conhecimento do consumo da população e, fazendo correlação com as demais informações acerca das características físicas da área de estudo, foi possível realizar a análise quanto à disponibilidade em relação à demanda de água.

\section{RESULTADOS E DISCUSSÃO}

Para atender a demanda de água para abastecimento doméstico em Ituiutaba, o município conta com os serviços sanitários da Superintendência de Água e Esgoto (SAE) desde 1967. A SAE é uma autarquia municipal que distribui $100 \%$ de água tratada para a população urbana utilizando dois mananciais para captação, o Ribeirão São Lourenço e o Rio Tijuco.

A SAE possui duas estações de captação, sendo a principal no Ribeirão São Lourenço (Figura 2), que foi a única estação disponível por muitos anos e, a estação reserva, no médio curso do rio Tijuco (Figura 03) inaugurada em dezembro de 2002 para suprir o aumento na demanda de água impulsionada pelo crescimento demográfico. A estação reserva possuí capacidade total de captação de $197 \mathrm{~L} / \mathrm{s}$ com uma adutora que liga as duas estações.

Figura 2 - Estação de captação principal no Ribeirão São Lourenço.

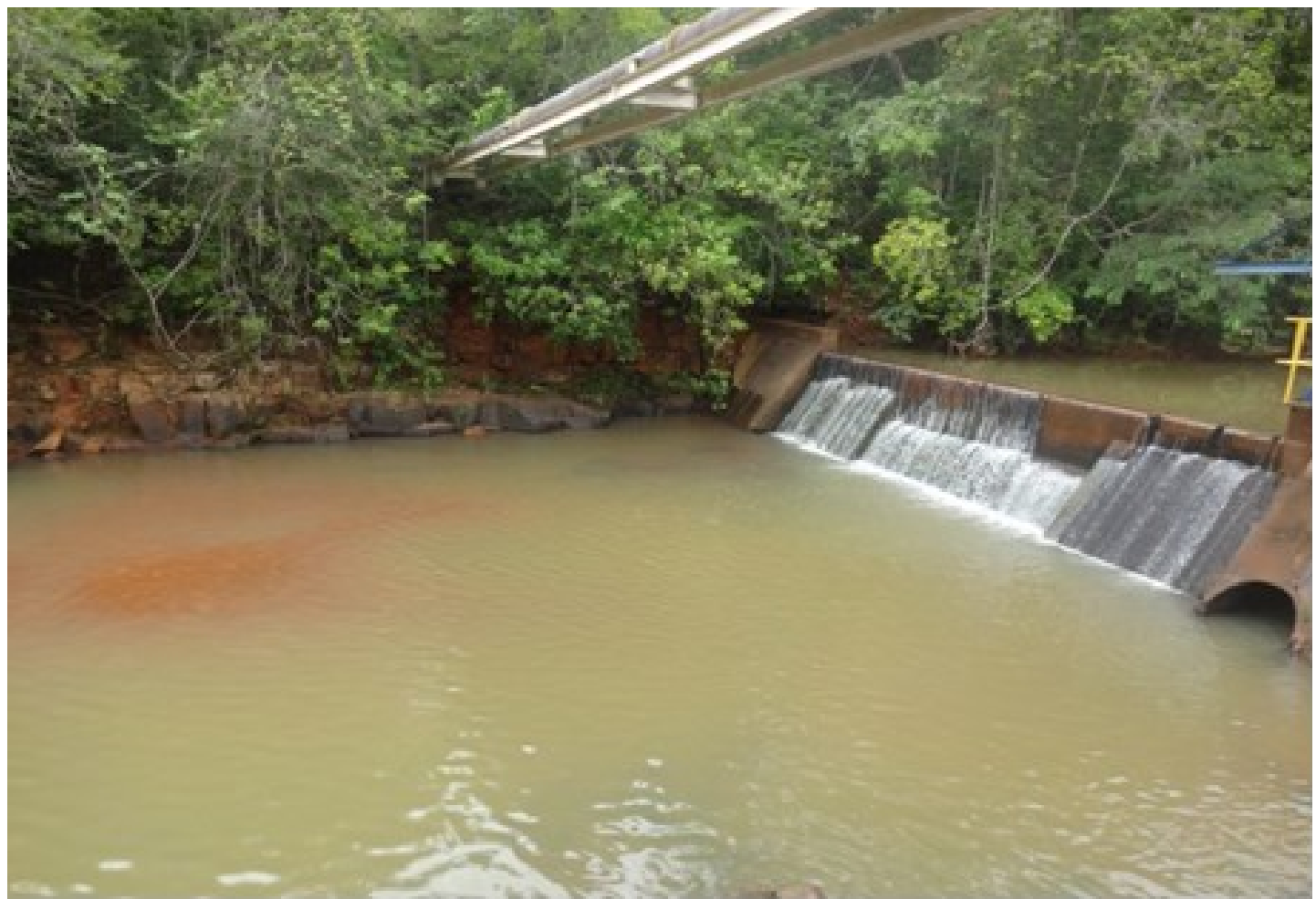

Fonte - SAE (2019) 
Figura 2 - Estação de captação reserva localizada no médio curso do rio Tijuco.

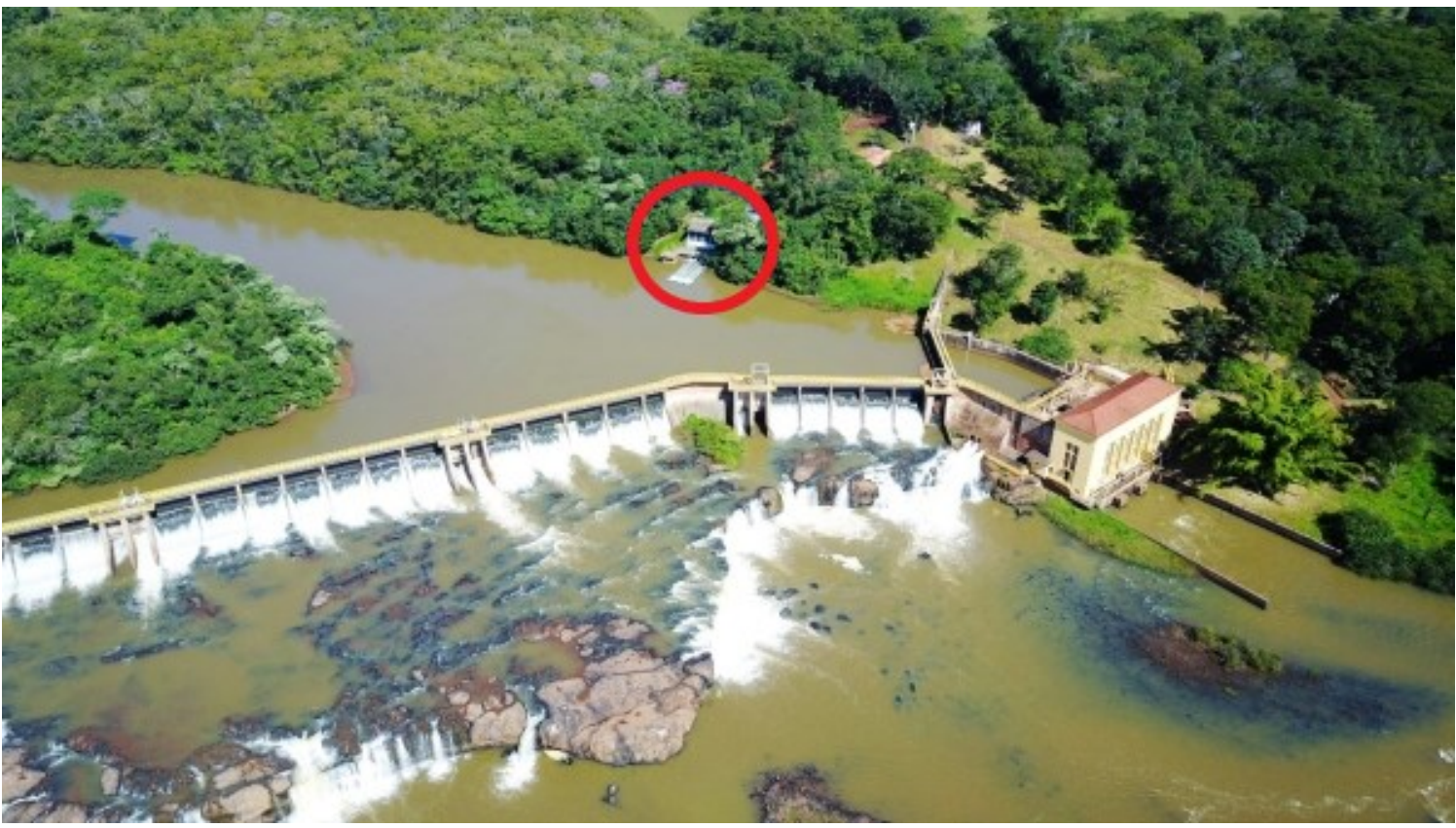

Fonte - SAE (2019).

Desde 2015 tem sido adotado de forma consecutiva, sempre no mês de outubro, o rodizio de abastecimento de água em toda a área urbana. Tal fato gera dúvidas em relação à disponibilidade hídrica para o abastecimento doméstico da cidade e levanta uma questão sobre o motivo disso acontecer nos últimos anos.

Segundo informações da SAE, nos últimos anos, houve um aumento de cerca de 20 conjuntos habitacionais na cidade. Para acompanhar esse crescimento urbano acelerado, foram necessárias obras de ampliação das redes de abastecimento de água. O sistema de abastecimento é composto por 5 estações elevatórias com motor bomba, 4 adutoras de ferro fundido, 16 reservatórios que somam capacidade total de armazenamento para $11.113 \mathrm{~m}^{3}$ de água e, a extensão total da rede de distribuição é de 483.677,73 metros.

De acordo com a informação do Quadro 1, com a vazão do Ribeirão São Lourenço de 380 L/s e a do Rio Tijuco de $197 \mathrm{~L} / \mathrm{s}$, calcula-se, com base na recomendação da ONU de consumo diário por pessoa (de 110 litros por dia, por pessoa) e conhecendo o número de habitantes da cidade, que haja oferta de água suficiente nos mananciais para atender o consumo de água da população. No entanto, a vazão dos mananciais está sujeita as variações do clima, especialmente, eventos climáticos pluviométricos como a chuva, por exemplo, de modo que a disponibilidade hídrica sofrerá variações ao longo do tempo. Assim como o clima, o consumo de água da população também pode variar tornando a disponibilidade hídrica insuficiente para o abastecimento doméstico.

Quadro 1 - Vazão para captação e outorga de funcionamento das estações.

\begin{tabular}{c|c|c}
\hline Captação Superficial & Vazão (I/s) & Outorga \\
\hline Ribeirão São Lourenço & $380 \mathrm{l} / \mathrm{s}$ & Portaria 891/2001 \\
\hline Rio Tijuco & $197 \mathrm{l} / \mathrm{s}$ & $\begin{array}{c}\text { Protocolo para renovação da Outorga } \\
\text { n. } 530779 / 2012\end{array}$ \\
\hline
\end{tabular}

Fonte - ARSAE - MG (2014). 
O resultado do balanço hídrico com dados de um período de vinte e um anos, (1987 a 2018) aponta os níveis de entrada e saída de água do solo e identificou os períodos secos e chuvosos do regime pluviométrico. Nos gráficos a seguir estão evidentes duas estações bem definidas para esses períodos, de acordo com o excedente e déficit hídrico apresentado em determinados meses do ano.

No Gráfico 1 se observa um excedente hídrico entre 75 e 170mm nos meses de janeiro, fevereiro e março que define a estação verão, a considerar os meses com maior número de dias contemplados com o evento da precipitação. O mês de maior precipitação é o mês de janeiro, registrando um excedente acima de $150 \mathrm{~mm}$ em relação aos outros meses do ano.

Gráfico 1 - Balanço hídrico de 21 anos de 1998 a 2018.

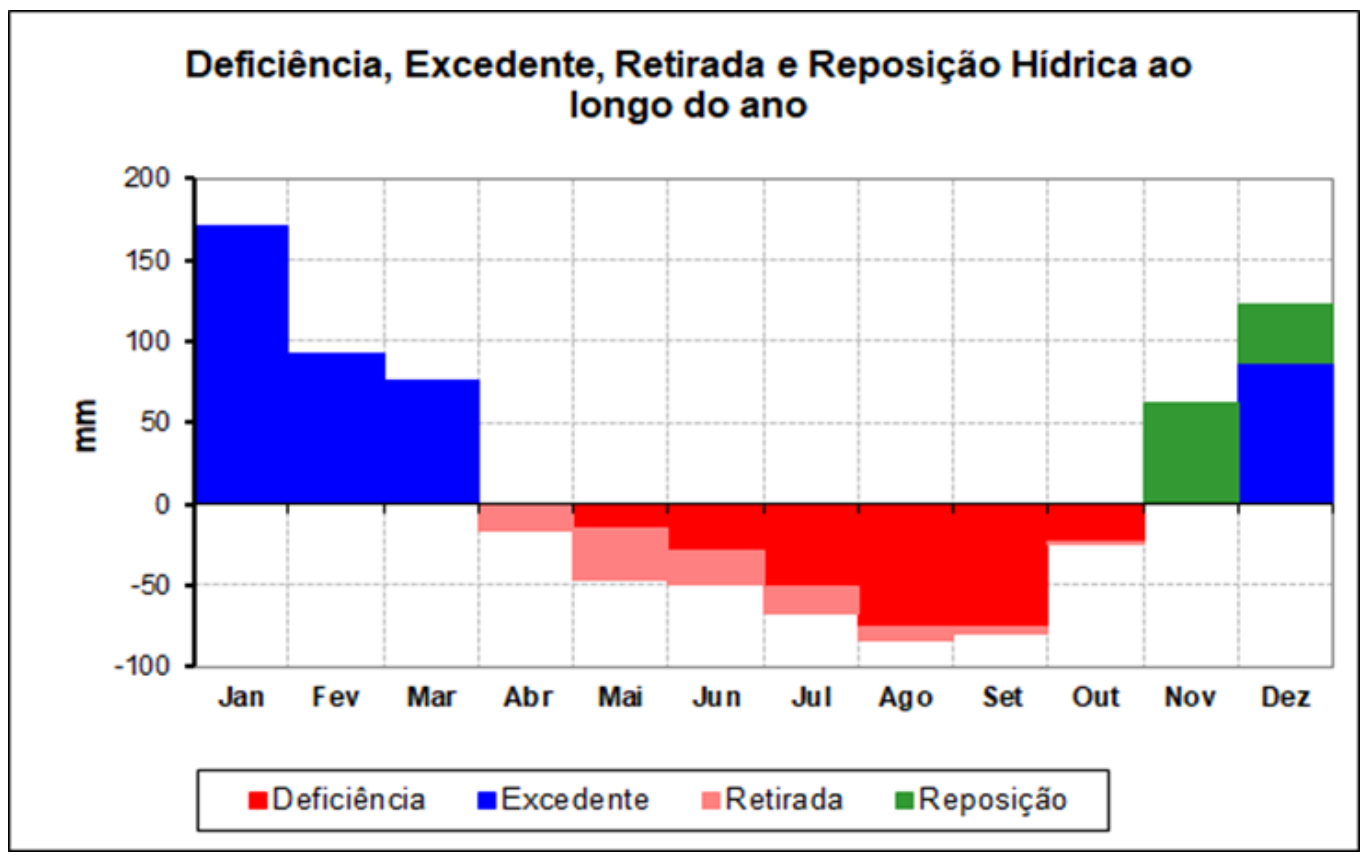

Fonte - ANA (2019).

O déficit hídrico, que se traduz como precipitações de valores inferiores aos de evapotranspiração das plantas, é observado nos meses de julho, agosto e setembro, definindo a estação inverno. Agosto e setembro apresentam o mesmo valor e são os meses de maior déficit hídrico do ano. Os valores de excedente e déficit são de suma importância para se desenvolver um planejamento mais eficiente dos recursos hídricos, buscando assim, garantir o abastecimento domestico para um período mais duradouro.

No Gráfico2 são mostrados os valores médios de precipitação, evapotranspiração (ETP), e evapotranspiração real (ETR). A ETP corresponde a quantidade de água perdida para a atmosfera pela transpiração das plantas e, ETR corresponde a quantidade de água perdida para a atmosfera nas condições reais de fatores atmosféricos e condições do solo. As plantas sugam água do solo e liberam para a atmosfera através da transpiração, que somada à evaporação direta do solo forma a evapotranspiração.

Percebe-se em que períodos (meses) do ano os valores de precipitação estão acima dos valores de ETP e ETR, gerando um excedente hídrico e, quando esses valores começam a baixar gerando o deficiente hídrico. Até o mês de março existe mais entrada de água do que perda. A partir desse mês a perda de água pela evapotranspiração das plantas e pelas condições do solo supera a quantidade de chuva, atingindo seu valor mais baixo no mês de julho.

Somente no mês de novembro a precipitação volta a superar a perda de água por ETP e ETR. Esses resultados estão sintetizados no balanço hídrico apresentando essa contabilidade de entrada e saída de água no solo. O período mais seco do ano se inicia em abril e perdura até novembro, portanto, são seis 
meses com mais perda de água para a atmosfera, caracterizando o período seco, e seis meses com maior oferta pluviométrica, caracterizando o período chuvoso.

Gráfico 2 - Balanço hídrico normal mensal do período de 1998 a 2018.

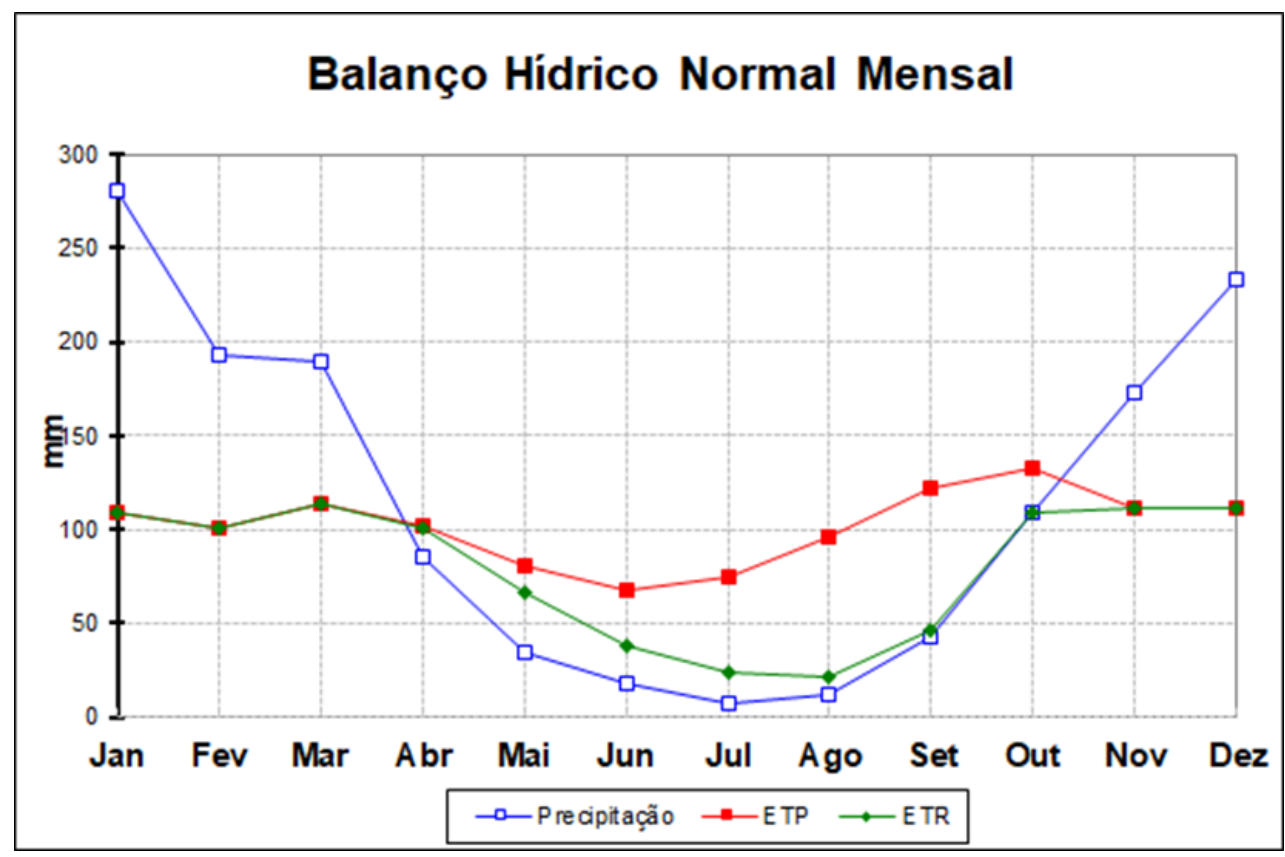

Fonte - ANA (2019).

Os dados de consumo de água disponibilizados pela SAE, são de um período de vinte e um anos, de 1998 e 2018, mesmo período utilizado para o balanço hídrico. Associando o gráfico do balanço hídrico com os valores médios mensais de consumo, observa-se que, no mesmo período, ocorre uma menor quantidade hídrica e os valores de uso doméstico continuam elevado, ou seja, não há redução do consumo, mesmo tendo uma recarga menor, devido ao período seco vigente.

De 1998 a 2018 o aumento do total anual foi de $2.409 .702 \mathrm{~m}^{3}$. No Gráfico 3 se observa a linha de tendência que indica o aumento do consumo total, havendo variações em alguns anos do período estudado. Dentro deste período houve aumento de população do município, principalmente na população urbana que é abastecida com água tratada pela SAE e, portanto, responsável pelo aumento do consumo.

Gráfico 3 - Consumo total anual de água em m³ de 1998 a 2018.

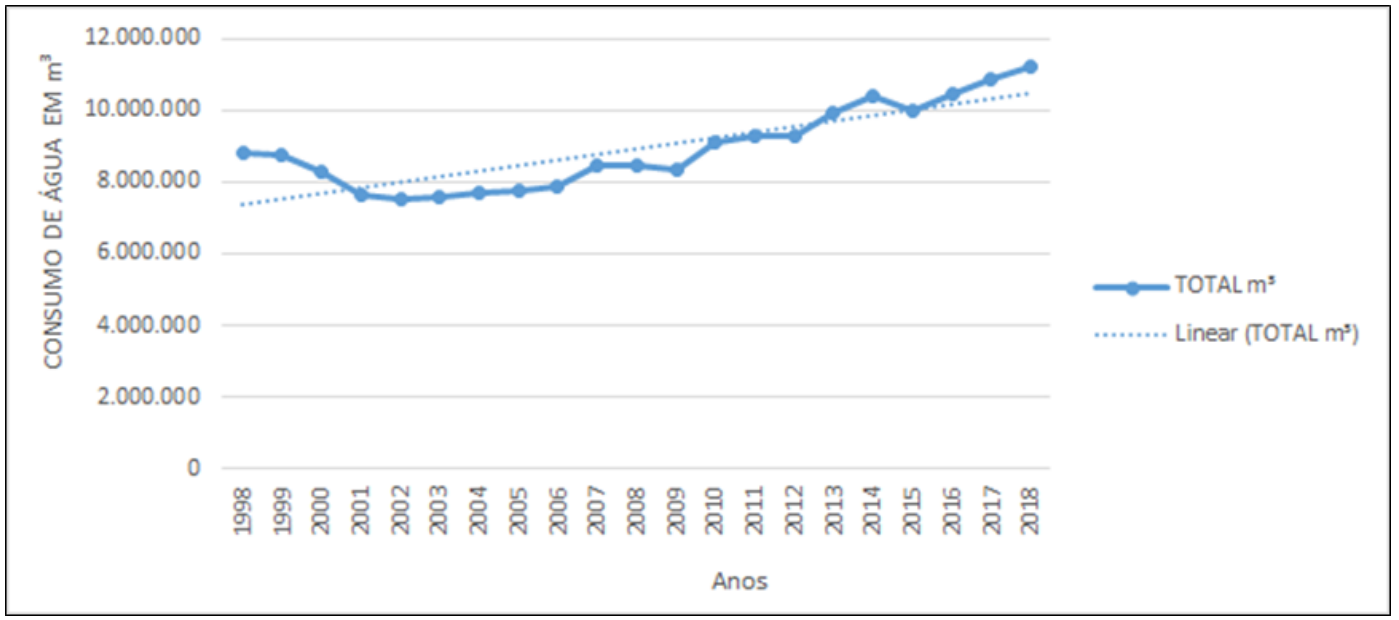

Fonte - SAE (2019) 
Para o ano de 2018, a população de Ituiutaba foi estimada em 104,067 habitantes e, de acordo com declaração do gerente de operações da SAE em agosto de 2017, a média de consumo diário de água por habitante é maior que a média nacional, que é de 160 litros. Em Ituiutaba a média do consumo diário de água por habitante é de 241,9 litros. Os dados populacionais, como os que são apresentados no Quadro 2 , comprovam a relação existente entre o aumento do consumo e o aumento da população urbana. Com essa informação o consumo de água foi analisado em relação à disponibilidade.

Quadro 2 - População do município de Ituiutaba/MG de 1950 a 2010.

\begin{tabular}{|c|c|c|c|}
\hline Ano & População Urbana & População Rural & População Total \\
\hline 1950 & 10.113 & 43.127 & 53.240 \\
\hline 1960 & 30.698 & 37.520 & 68.218 \\
\hline 1970 & 46.784 & 17.744 & 74.528 \\
\hline 1980 & 65.153 & 9.094 & 84.577 \\
\hline 1991 & 78.205 & 6.372 & 89.091 \\
\hline 2000 & 83.853 & 5.238 & 90.923 \\
\hline 2004 & - & - & 92.727 \\
\hline 2007 & 88.132 & 4.595 & 96.122 \\
\hline 2008 & - & - & 97.171 \\
\hline 2010 & 93.125 & 4.046 & \\
\hline
\end{tabular}

Fonte - IBGE (2019).

Entre 2000 e 2010, a população de Ituiutaba cresceu a uma taxa média anual de 0,87\%, enquanto no Brasil foi de $1,17 \%$ no mesmo período. Nesta década a taxa de urbanização do município passou de $94,12 \%$ para $95,84 \%$. A população urbana corresponde a 95,84\% e a população rural corresponde a 4,16\% (Atlas do Desenvolvimento Humano no Brasil, 2013).

É possível perceber o aumento da população urbana paralelamente a diminuição da população rural. A demanda por água na cidade acompanha esse aumento populacional. Calculando o volume de água produzido em $\mathrm{m}^{3}$ de cada ano e dividindo pelo número da população é possível chegar a um valor de consumo diário de água por pessoa. Em 2018 o consumo diário por pessoa foi de 295 litros.

No período seco, de maior deficiente hídrico, que ocorre durante o inverno nos meses de julho, agosto e setembro, ocorre o contrário. Devido à falta de chuvas, a umidade do ar atinge os níveis mais baixos do ano, as pessoas sentem desconforto térmico e tem maior necessidade no uso excessivo da água que utilizam também para limpar suas casas que sujam mais neste período de estiagem. O perfil de consumo para cada mês durante o período de 1998 a 2018 é evidenciado na Quadro 3 e Gráfico 4.

Quadro 3 - Totais mensais de consumo em $\mathrm{m}^{3}$ do período de 1998 a 2018.

\begin{tabular}{|c|c|c|c|}
\hline MESES & TOTAL & MESES & TOTAL \\
\hline Janeiro & 15.447 .993 & Julho & 15.968 .592 \\
\hline Fevereiro & 14.278 .636 & Agosto & 16.425 .978 \\
\hline Março & 15.598 .211 & Setembro & 16.322 .754 \\
\hline Abril & 15.196 .197 & Outubro & 16.407 .354 \\
\hline Maio & 15.611 .377 & Novembro & 15.370 .692 \\
\hline Junho & 15.163 .220 & Dezembro & 15.994 .699 \\
\hline
\end{tabular}

Fonte - SAE (2019). 
Como já apontado no resultado do balanço hídrico, é durante o verão, que compreende os meses de janeiro, fevereiro e março, que ocorre o período chuvoso com o maior excedente hídrico do ano. Nesta época do ano o ar está mais úmido, menos empoeirado, as chuvas são mais frequentes, a manutenção da limpeza nas residências torna-se mais fácil e as pessoas sentem menos necessidade de consumir água em excesso.

Gráfico 4 - Consumo total mensal de 1998 a 2018.

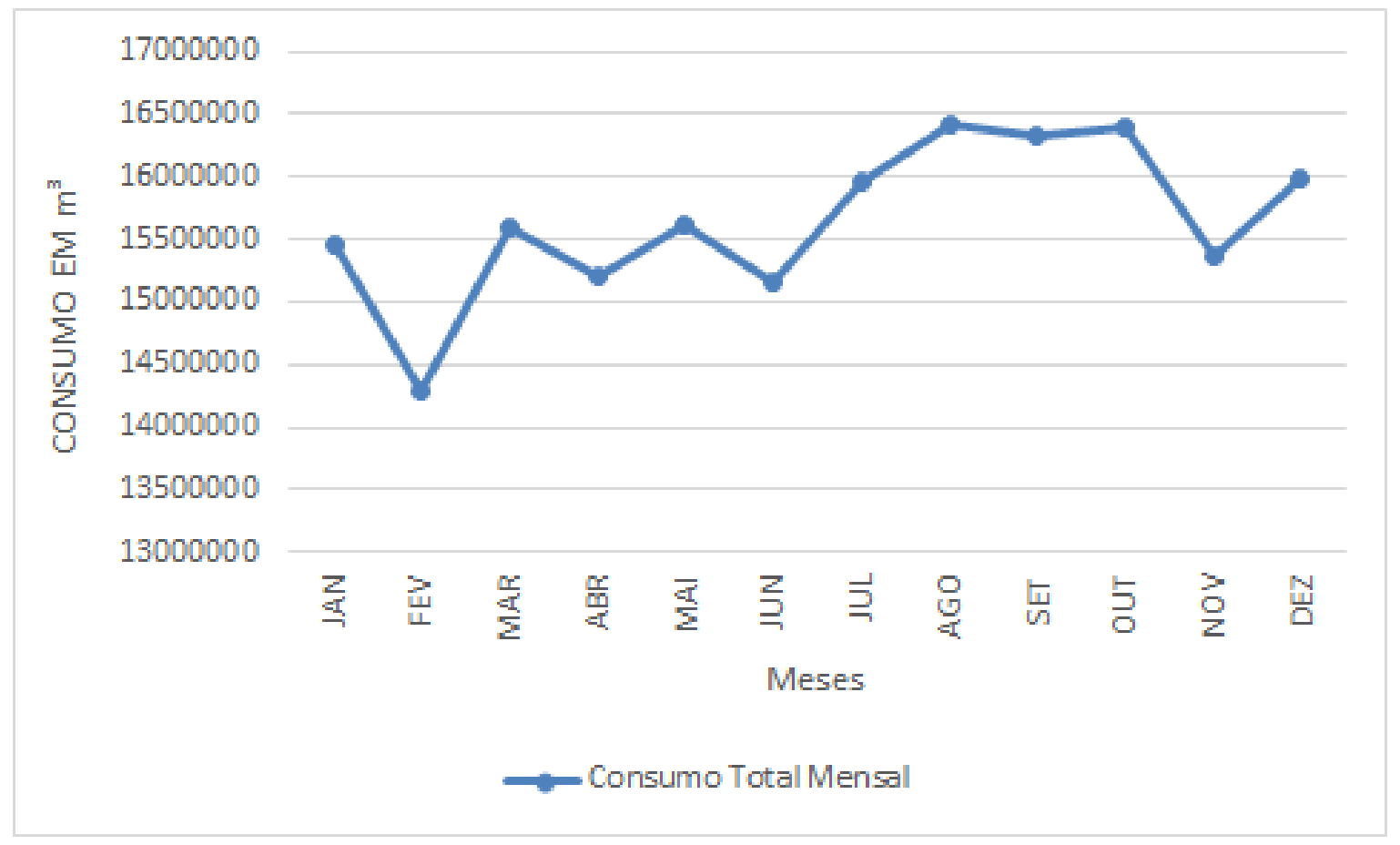

Fonte - SAE (2019)

\section{ANOS PADRÕES}

A partir dos dados do balanço hídrico, que traz um quadro geral da disponibilidade hídrica em Ituiutaba em uma série de vinte e um anos consecutivos, foi possível pormenorizar os resultados e analisar de forma mais específica a dinâmica entre temperatura, consumo e precipitação de três anos definidos como anos padrões que representam condições normais e extremas do clima.

\section{$>$ Ano Normal}

O ano definido como ano normal (metodologia dos Anos Padrão), com base nos dados do balanço hídrico foi o ano de 2004. Este ano mostra como tem sido a dinâmica do clima na maioria dos anos dentro do período estudado por não apresentar desvios extremos em relação a distribuição sazonal das chuvas.

O consumo total anual em 2004 foi de $7.688 .777 \mathrm{~m}^{3}$, para uma população estimada pelo IBGE em 90.923 habitantes. Através desses valores pode-se chegar a um valor de consumo diário por pessoa.

Verificou-se que o valor consumido diariamente por pessoa em Ituiutaba é de 231,6 litros de água no ano de 2004, definido como ano padrão normal. Esse consumo pode ser ainda maior se considerar apenas a população urbana, justifica-se aqui que, alguns distritos recebem água através de caminhões pipa, portanto recebem água da SAE, porém estes dados não foram informados para que se fizesse melhor avaliação do consumo. 
Ao analisar o Gráfico 5, os resultados são semelhantes ao quadro geral do balanço hídrico, com menor consumo de água durante o verão que é o período de maior concentração de chuvas e, consumo mais elevado durante o inverno, quando ocorre o período de estiagem. Durante o verão a temperatura média mensal se manteve entre $24^{\circ} \mathrm{C}$ e $26^{\circ} \mathrm{C}$ e no inverno a temperatura média esteve entre $21^{\circ} \mathrm{C}$ e $22^{\circ} \mathrm{C}$. O acumulo pluviométrico para o verão foi de $540 \mathrm{~mm}$ e o total para o ano foi de1.306,5 mm.

Gráfico 5 - Ano padrão normal (2004).

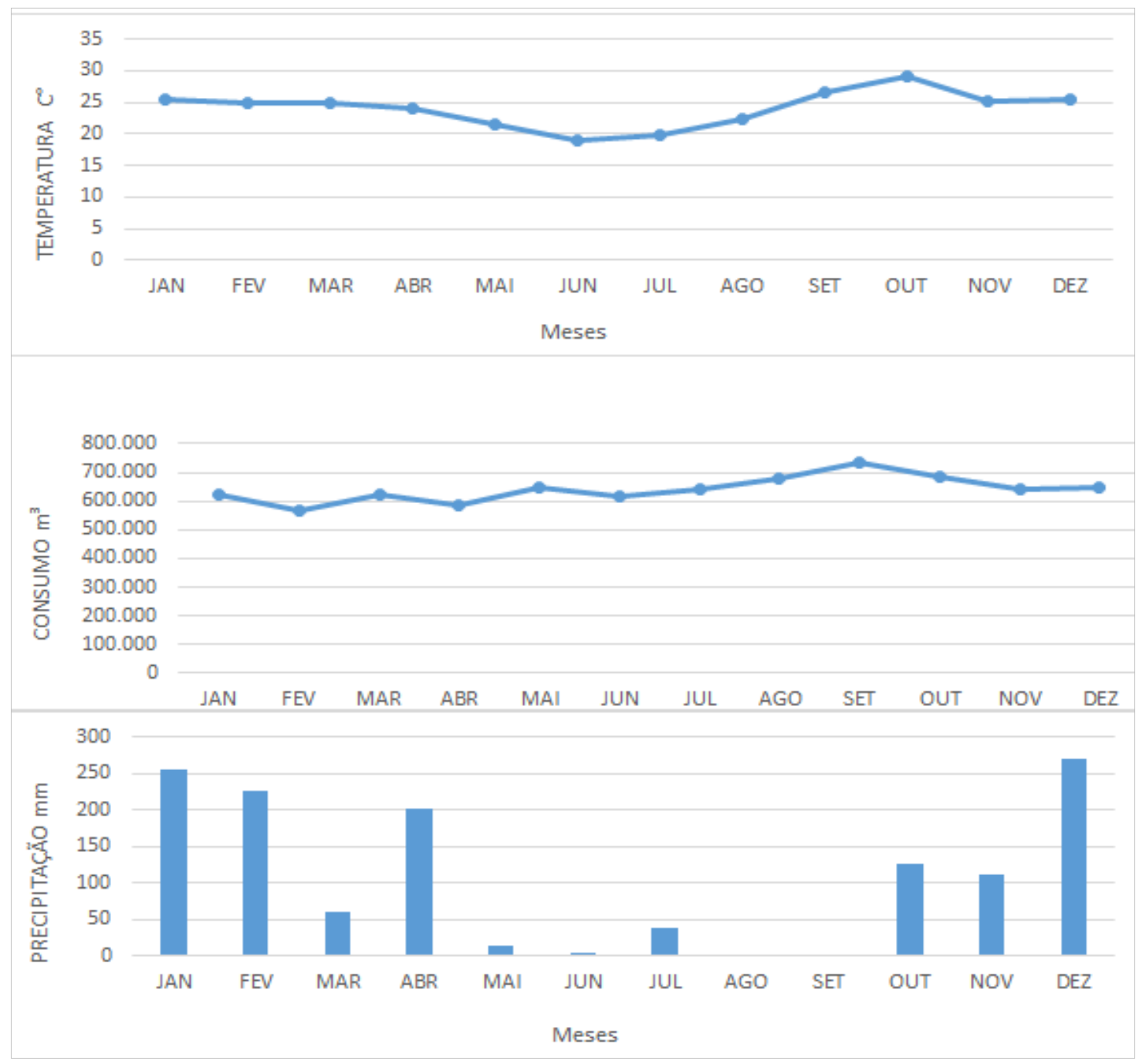

Fonte - ANA (2019).

\section{Ano Seco}

Conforme observado no Gráfico 6, o regime pluviométrico continua seguindo a mesma dinâmica demonstrada no balanço hídrico, as chuvas continuam concentradas no verão e atinge os registros mais baixos durante o inverno. Mesmo seguindo essa dinâmica de distribuição, o acúmulo total para o verão está bem abaixo em relação ao ano de 2004 e mais ainda em relação ao ano de 2008 (comparando com o Gráfico 9), principalmente no mês de fevereiro. A comparação se dá por serem anos atípicos.

O acúmulo durante o verão em 2007 foi de $438,8 \mathrm{~mm}$ e o acúmulo total do ano foi de $949,2 \mathrm{~mm}^{3}$. A diferença de 2004 para 2007 durante o período chuvoso é de $101,2 \mathrm{~mm}^{3} \mathrm{~A}$ temperatura média durante o verão se manteve em aproximadamente $25^{\circ} \mathrm{C}$ e durante o inverno variou entre $20^{\circ} \mathrm{C}$ e $25.3^{\circ} \mathrm{C}$. 
Gráfico 6 - Ano padrão seco (2007).

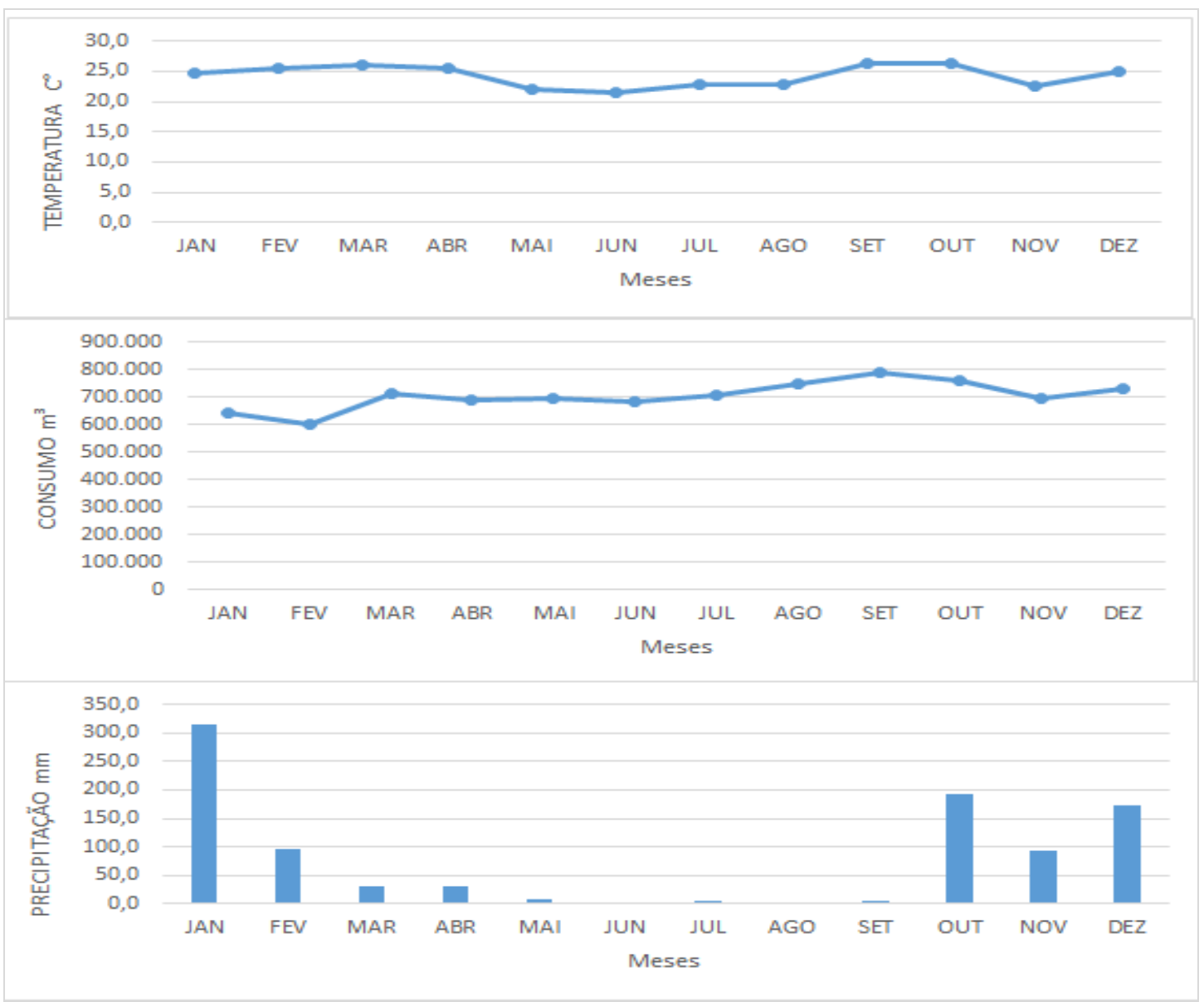

Fonte - ANA (2019).

Em 2007, o consumo total anual foi de $8.445 .643 \mathrm{~m}^{3}$, para uma população de 92.931 habitantes, sendo a população urbana de 88.132 habitantes. Com base nesses dados, aplicando novamente o cálculo explicado anteriormente, o consumo diário por pessoa foi de 262,5 litros, para um ano definido como ano padrão seco.

\section{Ano Chuvoso}

Pela análise do Gráfico 7, que demonstra a dinâmica climática em relação ao consumo para o ano de 2008, definido como ano padrão chuvoso, a maior concentração do regime pluviométrico continua sendo durante o verão e a menor concentração durante o inverno. Mas este ano se diferencia pelo acúmulo de chuvas muito superior em relação aos anos de 2004 e 2008 durante o verão.

A temperatura média durante o verão foi de $24{ }^{\circ} \mathrm{C}$ e variou de $20^{\circ} \mathrm{C}$ a $23^{\circ} \mathrm{C}$ durante o inverno. $\mathrm{O}$ menor consumo de água do ano foi no mês de fevereiro, que compreende o período de excedente hídrico, e o maior no mês de agosto, que é o mês com maior deficiente hídrico verificado no resultado do balanço hídrico.

O acúmulo pluviométrico durante o verão no ano padrão chuvoso foi de $923 \mathrm{~mm}$, e o total anual foi de $1703,4 \mathrm{~mm}$. No período chuvoso, a diferença para o ano normal é de $383 \mathrm{~mm}$ e, para o ano seco é de $821,8 \mathrm{~mm}$.

Por essa diferença durante o verão, analisando os resultados de todos os anos do período estudado, foi possível caracterizar 2004 como ano padrão normal, 2007 como ano padrão seco e 2008 como ano padrão chuvoso. 
Gráfico 7 - Ano padrão chuvoso (2008).

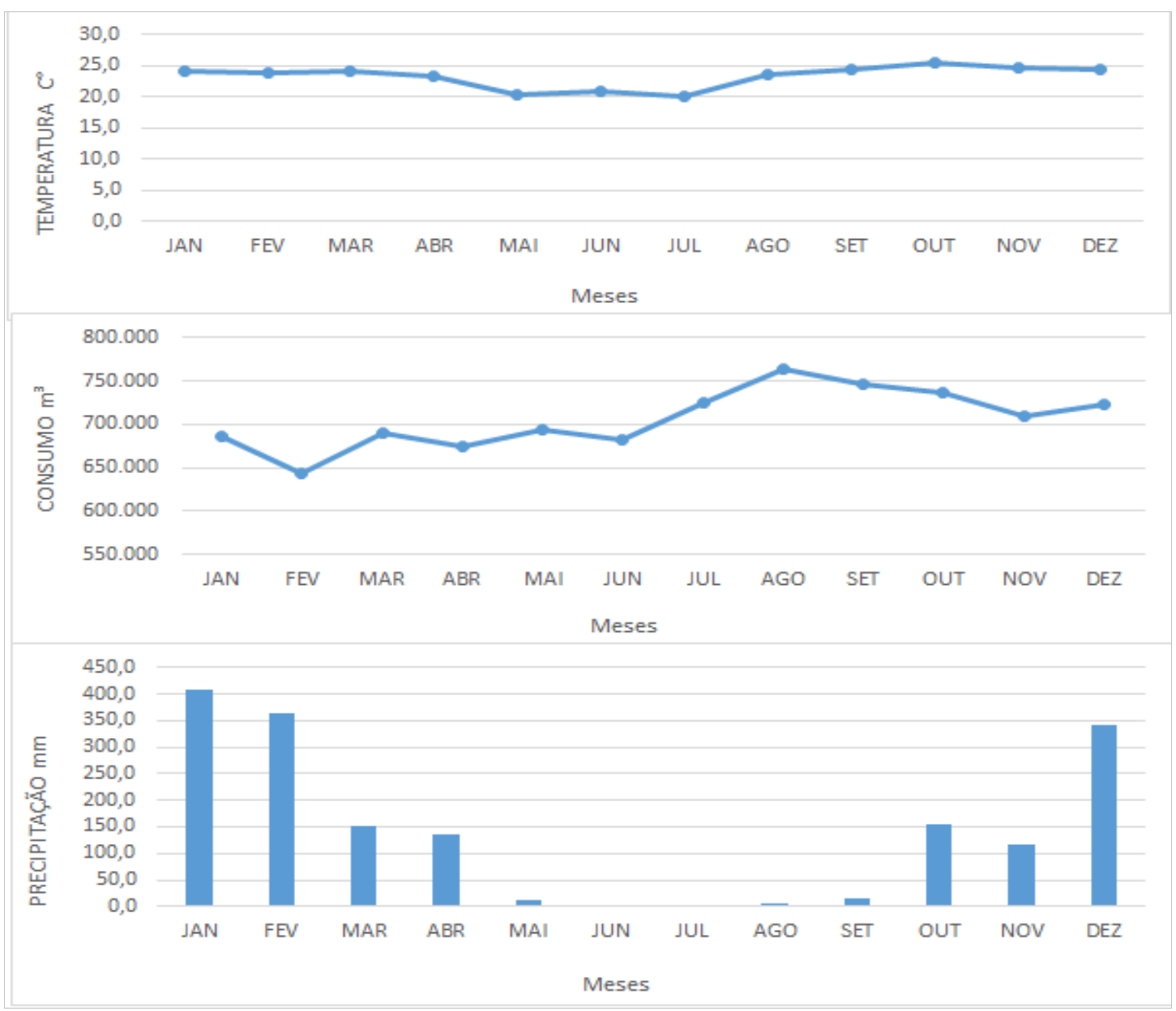

Fonte - ANA (2019).

Em 2008, o consumo total anual foi de $8.474 .085 \mathrm{~m}^{3}$ para uma população estimada em 96.122 habitantes. Calculando o consumo com base nesses dados, o consumo diário por pessoa é de 241,5 litros, para um ano definido como ano padrão chuvoso. Mais uma vez, o cálculo foi feito considerando a estimativa para população total por falta de informações referentes a população urbana e rural.

A análise dos três anos padrões confirma a ocorrência de um período chuvoso no verão e um período seco no inverno, variando somente no acumulo pluviométrico total que é maior em um ano do que em outros. O consumo de água, porém, não apresenta muita variação e é sempre elevado mesmo em um ano padrão seco como 2007, e os meses de maior consumo no ano são sempre agosto e setembro coincidindo com o período do deficiente hídrico do município.

\section{CONSIDERAÇÕES FINAIS}

Buscou-se com esta pesquisa, avaliar a questão hídrica para abastecimento doméstico na cidade de Ituiutaba - MG, identificando problemas de escassez de água atuais, de modo que se possa adotar medidas preventivas e de proteção para evita-los futuramente. A adoção de métodos adequados e a aquisição de dados pertinentes ao tema permitiu compreender a dinâmica do consumo na cidade em face a disponibilidade hídrica demonstrada no balanço hídrico.

A água tratada pela SAE é $100 \%$ distribuída somente na área urbana, o que torna a população urbana e as indústrias instaladas neste perímetro responsáveis por esse consumo. Por falta de informações exatas referentes aos dados da população urbana e rural o valor diário de consumo por habitante foi estimado com base em referências que nortearam os cálculos realizados, ou seja, levando em consideração a população urbana e população rural. 
Tanto nos cálculos que consideraram a população total do município, quanto nos que consideraram apenas a população urbana, os resultados apontam uma média de consumo elevada. No período estudado houve um aumento considerável da população urbana gerando consequente aumento na demanda hídrica. Em função disso a SAE tomou a providência de construir mais uma estação de captação no médio curso do Rio Tijuco, para ser acionada em períodos de baixa vazão do Ribeirão São Lourenço.

No entanto, a vazão dos mananciais, ou seja, a oferta hídrica está sujeita às variações climáticas e não se mantém estável durante o ano todo, ao passo, que a demanda é sempre crescente em função do aumento da população. Levando em consideração a recomendação da ONU de que uma pessoa não necessita de mais do que 110 litros de água por dia para suprir suas necessidades, e que a média de consumo nacional está em torno de 160 litros por dia por habitante, fica evidente o elevado consumo de água da população em Ituiutaba com uma média de consumo de 241,9 litros por dia, por habitante.

Porém, nos dados de consumo disponibilizados pela SAE consta o consumo total de água da área urbana, o que inclui o consumo industrial e o consumo doméstico, não sendo possível tomar conhecimento sobre qual dos usos tem um consumo maior de água tratada.

Mesmo assim, a análise das informações sobre o número de habitantes do município, caracterização da área de estudo, períodos de maior consumo e de maior recarga de água e definição de anos padrões, permitiu que a disponibilidade hídrica fosse avaliada por comparação e correlação de dados.

O resultado do balanço hídrico e a caracterização física da área de estudo apontam que existe potencial e boa disponibilidade hídrica para abastecimento doméstico, tanto pelo regime pluviométrico quanto pelas cotas altimétricas, declividade do relevo e condições do solo que possuí boa capacidade para armazenamento de água.

O problema maior em relação a disponibilidade hídrica é o fato de que o período de maior consumo no ano coincide com o período de menor recarga de água no município e maior perda de água para a atmosfera. Uma forma de equilibrar a situação seria reduzir o consumo de água (através de campanhas de educação ambiental e um consumo mais consciente) em períodos que as bacias hidrográficas recebem menor recarga de água, na tentativa de acompanhar o regime pluviométrico e evitar a escassez.

A população conta com serviços de qualidade prestados pela SAE que segue fazendo melhorias na rede de distribuição para acompanhar a demanda hídrica. Mas, mesmo com fatores que favorecem a disponibilidade hídrica para o abastecimento da cidade, se a população e as indústrias não adotarem uma postura mais consciente e sustentável em relação ao consumo, em alguns anos, essa disponibilidade pode estar comprometida em certos períodos do ano.

Até o momento, o rodízio no abastecimento de água adotado pela SAE tem controlado a situação, pois, a população não passa mais de 24 horas sem água, e no período de racionamento, deve controlar suas atividades e utilizar a água armazenada nas caixas d'águas de suas residências somente para necessidades básicas. $O$ desperdício deve ser evitado e qualquer vazamento de água na rede de distribuição deve ser imediatamente comunicado a SAE para que seja resolvido o mais rápido possível.

\section{REFERÊNCIAS}

AMORIM NETO, M. S. Balanço hídrico segundo Thornthwaite e Mather (1955). Petrolina: EMBRAPA, 1989. p. $1-18$.

ANA. Agência Nacional de Águas. Disponível em: < https://www.ana.gov.br/>. Acesso em: 05 de jan. de 2019.

ARAGÃO, M.J. História do Clima. Rio de Janeiro: Interciência, 2009.

BACCARO. C. A. D.; SANTOS, L. Caracterização Geomorfológica da Bacia do Rio Tijuco, 2014.

Disponível em: <http://www.seer.ufu.br/index.php/caminhosdegeografia/article/view/15321>. Acesso em: 04 de abr. de 2019.

ALVARENGA, M.I.N.; BARISON, M.R.; DIAS PONS, N.A. Solos. In: Ciências Ambientais para engenharia. 1. ed. Rio de Janeiro: Elsevier, 2014. 55 - 82.

ATLAS DO DESENVOLVIMENTO HUMANO NO BRASIL. Ituiutaba, MG. Disponível em: < http://atlasbrasil.org.br/2013/pt/perfil_m/ituiutaba_mg>. Acesso em: 15 de jul. de 2019. 
BOTELHO, R. G. M. Bacias Hidrográficas Urbanas. In: GUERRA, J. T. Geomorfologia urbana. Rio de Janeiro: Betrand Brasil, 2011.

BRASIL. Ministério da Ciência e Tecnologia. Curso de Aperfeiçoamento em Gestão de Recursos Hídricos. Disponível em: <http://capacitacao.ana.gov.br/Lists/Editais_Anexos/Attachments/23/05. Recursos HD-220909.pdf>. Acesso em: 12 out. 2019.

Ministério do Meio Ambiente. Água. Disponível em:

<http://www.mma.gov.br/estruturas/secex_consumo/_arquivos/3\%20-\%20mcs_agua.pdf >. Acesso em: 13 out. 2019.

Portal Brasil. Entenda as principais regras do Código Florestal.

$\overline{<h t t p: / / w w w . b r a s i l . g o v . b r / m e i o-a m b i e n t e / 2012 / 11 / e n t e n d a-a s-p r i n c i p a i s-r e g r a s-d o-c o d i g o-f l o r e s t a l>. ~}$ Acesso em: 13 out. 2018.

Lei $\mathbf{n}^{\circ} \mathbf{1 2 . 7 2 7}$ de 17 de outubro de 2012. Disponível em: <http://www.planalto.gov.br/ccivil_03/_ato2011-2014/2012/lei/L12727.htm>. Acesso em: 14 out. 2017.

BITTENCOURT, C.; SILVA DE PAULA. Tratamento de água e efluentes Fundamentos de saneamento ambiental e gestão de recursos hídricos. 1. ed. São Paulo: Érica, 2014.

CALHEIROS, H. C.; SILVA, B. C. Águas Superficiais In: CAPAZ, R. S; HORTA NOGUEIRA, L. A. Ciências ambientais para engenharia. 1. ed. Rio de Janeiro: Elsevier, 2014. 85 - 122.

CBH PARANAÍBA. O que é comitê de bacia. Disponível em: <http://cbhparanaiba.org.br/cbhparanaiba/o-que-e-comite-de-bacia>. Acesso em: 15 de out. de 2018.

COSTA, R. A.; SILVA, G. A. Paisagem e fragilidade ambiental natural da bacia hidrográfica do Ribeirão São Lourenço, Ituiutaba/Prata - MG. Disponível em:

<http://webcache.googleusercontent.com/search?q=cache:FWRvJzraj5MJ:www.seer.ufu.br/index.php/cam inhosdegeografia/article/view/16635/9245+\&cd=1\&hl=pt-BR\&ct=clnk\&gl=br>. Acesso em: $04 \mathrm{de} a b r$. de 2019.

EMBRAPA. Código florestal. Disponível em: <https://www.embrapa.br/codigo-florestal>. Acesso em: 11 out. 2018.

FOLI, A. C. A.; COSTA, R. A. O Clima Urbano da Cidade de Ituiutaba - MG: análise do campo termohigrométrico em episódios de inverno-verão. Brazilian Geographical Journal: Geosciencies and Humanities research médium. Ituiutaba, v7, n 1. P. 71 - 99, jan/jun 2016.

GROTZINGER, J.; JORDAN, T. Para entender a Terra. Tradução de luri Duquia Abreu. 6. ed. Porto Alegre: Brokman, 2013.

GUERRA, Antonio J. T. et al. Geomorfologia e meio ambiente. 11. ed. Rio de Janeiro: Bertrand Brasil, 2012.

MENDES, P. C.; QUEIROZ, A. T. Caracterização Climática do Município de Ituiutaba - MG. In:

PORTUGUEZ, A. P.; MOURA, G. G.; COSTA, R. A. (Orgs). Geografia do Brasil Central: enfoques teóricos e particularidades regionais. Uberlândia: Assis Editora, 2011. P. 333 - 353.

MONTEIRO, C. A. F. Da Necessidade de Um Caráter Genético à Classificação Climática. Revista Geográfica, Instituto Pan - Americano de Geografia e História, Rio de Janeiro, n ${ }^{\circ}$ 7, tomo XXXI, p. 29 44, 1962. Disponível em: <https://www.jstor.org/stable/40996656?seq=1\#page_scan_tab_contents.

Acesso em: 10 de nov. de 2019.

PORTAL DOS COMITÊS. PN3 - CBH do Baixo Rio Paranaíba. Disponível em:

<http://comites.igam.mg.gov.br/comites-estaduais-mg/pn3-cbh-baixo-rio-paranaiba>. Acesso em: $10 \mathrm{de}$ mai. de 2019.

PRADO, V. G. T. J.; SOUSA, R. R. Mapa Pluviométrico do Triângulo Mineiro. Iniciação Científica (Relatório Final). UFU, FACIP: Ituiutaba, 2010, 38 p.

RICHTER, B. Em busca da água: um guia para passar da escassez à sustentabilidade. São Paulo: Oficina de Textos, 2015.

RIBEIRO, A.G. O Consumo de Água em Bauru - S.P. O tempo cronológico e o tempo meteorológico aplicados na elaboração de subsídios à previsão de demanda de água. Dissertação de mestrado. F.F.L.C.H. - USP, 1975. 
SAE: SUPERINTENDÊNCIA DE ÁGUA E ESGOTOS DE ITUIUTABA. Histórico. Disponível em: < http://www.saeituiutaba.com.br/?arq=2>. Acesso em: 29 ago. 2018.

SAVEH Sistema de auto avaliação da eficiência hídrica. A disponibilidade de água no mundo e no Brasil. Disponível em: < https://saveh.com.br/artigos/a-disponibilidade-de-agua-no-mundo-e-no-brasil/> . Acesso em: 08 de out. de 2018.

SANTOS, A. R. Balanço hídrico segundo Thornthwaite e Mather. Disponível em: <http://www.mundogeomatica.com.br/CL/ApostilaTeoricaCL/Capitulo10-BalancoHidrico.pdf.> Acesso em: 23 de jun. de 2018.

TAVARES, C.T. Critérios de escolha de anos padrões para análise rítmica. Geografia. Vol 1/ Abril $1976 / N^{\circ} 1$.

THORNTHWAITE, C.W.; MATHER, J.R. (1955). "The water balance”. Centerton: Drexel Institute of Technology, Laboratory of Climatology. Publications in Climatology, v. 8, n. 1. 104p.

TUNDISI, J. G.; TUNDISI, T. M. Recursos hídricos no século XXI. São Paulo: Oficina de Textos, 2011. VITTE, A. C.; GUERRA, A. J. T. (Orgs.). Reflexões sobre a Geografia Física no Brasil. 7. ed. Rio de Janeiro: Bertrand Brasil, 2014.

Recebido em: 12/05/2020

Aceito para publicação em: 07/08/2020 